\title{
Uniparental Disomy and Genome Imprinting: an Overview
}

\author{
E. Engel \\ University of Geneva Medical School, Geneva, Switzerland
}

The following paper is concerned with potential changes in the normal epigenetic process in a diploid individual, when a chromosome pair or segment is inherited from one parent only, instead of the expected biparental contribution. This aberrant mode of transmission arises from the high rate of gamete aneuploidy in humans. It has received the name uniparental disomy (UPD), and has emerged as an important factor in the new field of nontraditional inheritance, depicted in Table 1.

The following definitions may foster a better understanding of this discussion.

$U P D$ is the inheritance of both copies of a chromosome [or chromosomal segment(s)] from a single parent, instead of the normal biparental transmission of the pair. In isodisomy, the two uniparental copies are identical, being derived from the same parental chromosome. In heterodisomy, the two uniparental chromosomes are different, being derived from the homologues of a pair.

Table 1 - Instances of non-traditional inheritance

I. Di- or trinucleotide repeat expansion (i.e. anticipation)

II. Mitochondrial inheritance: only matroclinous (normal or aberrant)

III. Epigenetic modifications (both normally or aberrantly transmitted)

a) Normal parental imprinting

b) Abormal parental imprinting

1. Chromosome duplication

2. Chromosome deletion

3. Chromosomal translocations and inversions

4. UPD

5. Gene mutations

6. Imprinted gene mutations

7. Imprinted control element mutations 

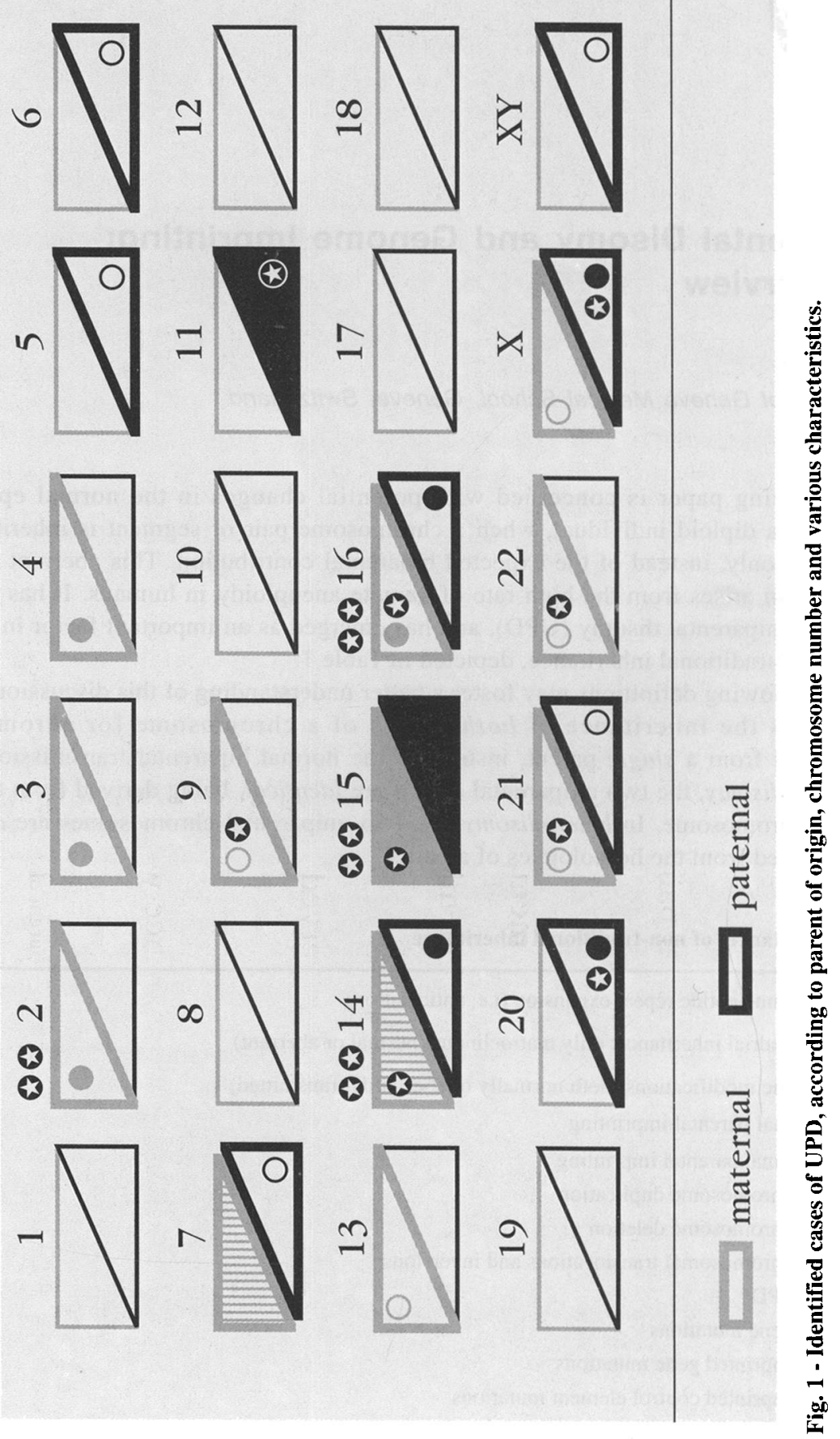


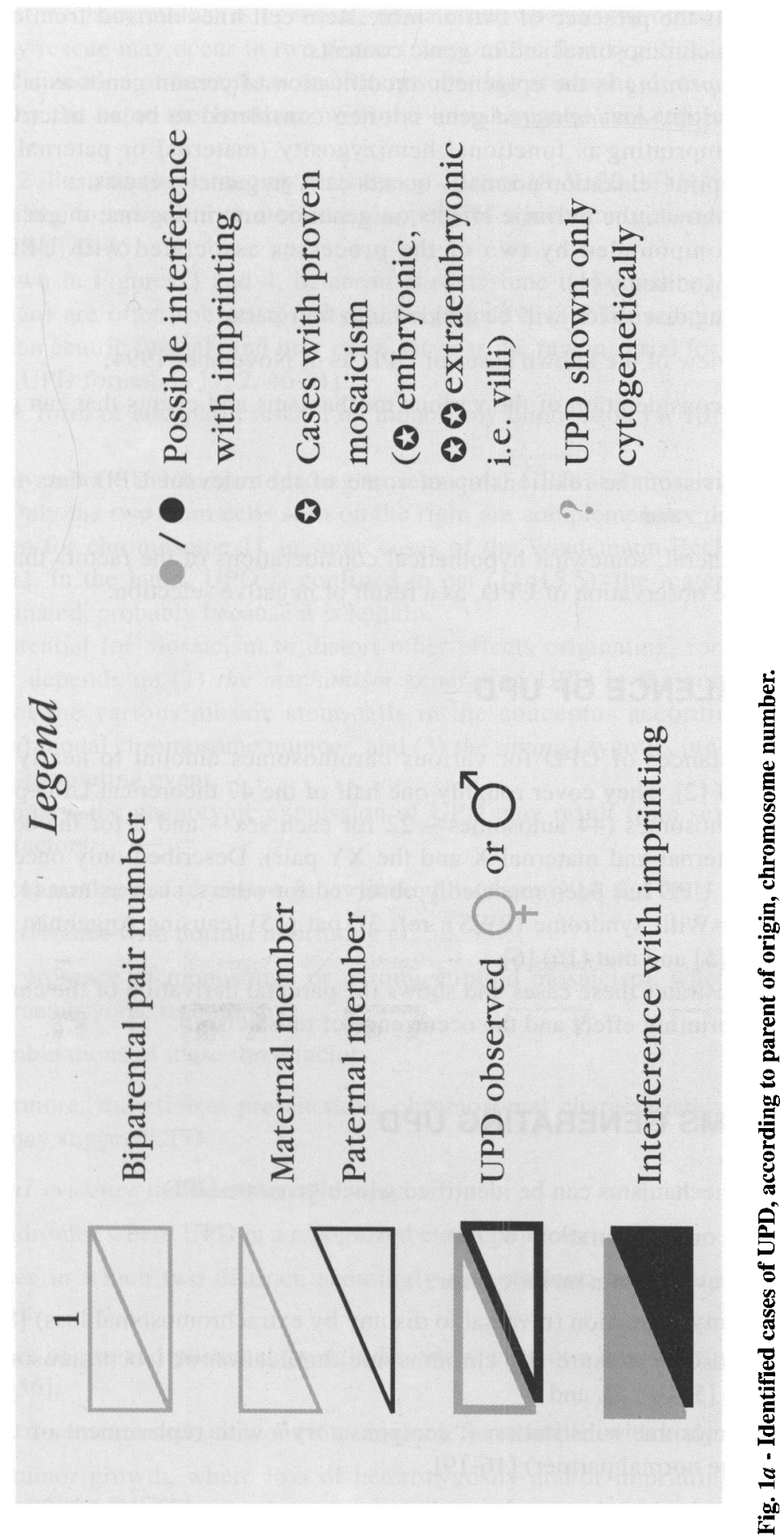




\section{E. Engel}

Mosaicism is the presence of two or more stem cell lines derived from one zygote, having different chromosomal and/or genic contents.

Genomic imprinting is the epigenetic modification of certain genes as a function of their parental origin. An imprinted gene is often considered to be an inactivated gene. The result of imprinting is functional hemizygosity (maternal or paternal) for some allelic pairs. Imprint relaxation normally occurs early in gametogenesis.

As will be shown, the intrinsic effects on genomic imprinting one might attribute to UPD can be compounded by two of the processes associated with UPD, namely mosaicism and isodisomy [1].

The following discussion will be divided into four parts:

1. an overview of the known cases of UPD as of November 1994;

2. a broad consideration of the various mechanisms and events that can give rise to UPD;

3. an analysis of the relationship of some of the relevant UPD data to genomic imprinting, and

4. some general, somewhat hypothetical considerations of the factors that may preclude the observation of UPD, as a result of negative selection.

\section{THE PREVALENCE OF UPD}

The known instances of UPD for various chromosomes amount to nearly 100 as of November 1994 [2]. They cover roughly one half of the 47 theoretical UPD possibilities for entire chromosomes (44 autosomes - 22 for each sex - and 3 for the sex chromosomes - the paternal and maternal $X$ and the XY pair). Described only once so far for some members, UPD has been repeatedly observed for others, such as mat (15) [responsible for Prader-Willi syndrome (PWS); ref. 3], pat (15) [causing Angelman syndrome; ref. 4], mat (7) [5] and mat (16) [6].

Figure 1 illustrates these cases and shows the parental derivation of the chromosome, the genome imprinting effect and the occurrence of mosaicism.

\section{MECHANISMS GENERATING UPD}

Three general mechanisms can be identified which generate UPD:

1. gamete complementation $[6,7]$;

2. mitotic reversal of a meiotic error:

a) trisomy correction (reversal to disomy by extrachromosomal loss) [8, 9];

b) monosomy erasure (by chromosome duplication or isochromosome formation) $[5,10-15]$, and

c) chromosome substitution ("compensatory" with replacement of the marker by the normal partner) [16-19];

3. mitotic recombination (exchange between homologue chromatids) [20, 21$]$. 
The first mechanism does not generate mosaicism, whereas the other two can.

Trisomy rescue may occur in two distinct ways at the first zygotic cleavage by chromatid nondisjunction at metaphase or chromosome lag at anaphase, or at various stages thereafter by the same mechanisms, with the initial zygotic makeup preserved in one stem cell.

Figure 2 illustrates how trisomy rescue may operate $[8,9,22-37]$ by reduction to disomy according to two distinct mechanisms, both of which can generate mosaicism, in theory at least [38-45].

As shown in Figures 3 and 4, balanced chromosome translocations (reciprocal and Robertsonian) are often subject to irregular segregation (3:1 for reciprocal and 2:1 for Robertsonian centric fusion), and may often serve as the raw material for mitotic trisomy rescue and UPD formation [1, 2, 46-51].

Another form of aneuploid rescue, by monosomy duplication $[4,10]$ is illustrated in Figure 5 .

A purely mitotic mechanism leading to segmental UPD and mosaicism is shown in Figure 6. Only the two stem cells seen on the right are complementary disomic types, as may happen for chromosome 11 in some cases of the Wiedemann-Beckwith syndrome (WBS) [21]. In the latter, UPD is confined to pat (11p15.5), the maternal counterpart being eliminated, probably because it is lethal.

The potential for mosaicism to distort other effects originating, for example, from imprinting depends on (1) the mechanism generating UPD in the conceptus, (2) the selection of the various mosaic stem cells in the conceptus according to e.g. their makeup and modal chromosome number, and (3) the timing (zygotic, pre-or postnatal) of the mosaic-generating event.

In summary, the phenotypic expression of UPD may result from several isolated or combined factors:

1. the unmasking of recessive genes through isodisomy $[4,6,10]$;

2. interference with normal imprinting $[1,52,53]$;

3. the presence of monosomic or trisomiceuploid mosaicism, whether embryonic, extraembryonic or both, and

4. combinations of these three factors.

Furthermore, the clinical presentation, chromosomal characteristics and molecular evidence may suggest UPD.

Clinical evidence includes the following:

1. syndromes where UPD is a recognized etiologic factor;

2. cases in which two distinct, seemingly independent, conditions are associated [54];

3. cases of pre-and postnatal growth disorders without a known explanation [4, 10 , 54-56];

4. the aforementioned situations if associated, for example, with body asymmetry, and

5. in tumor growth, where loss of heterozygosity and/or imprinting are important factors $[20,21,57]$. 


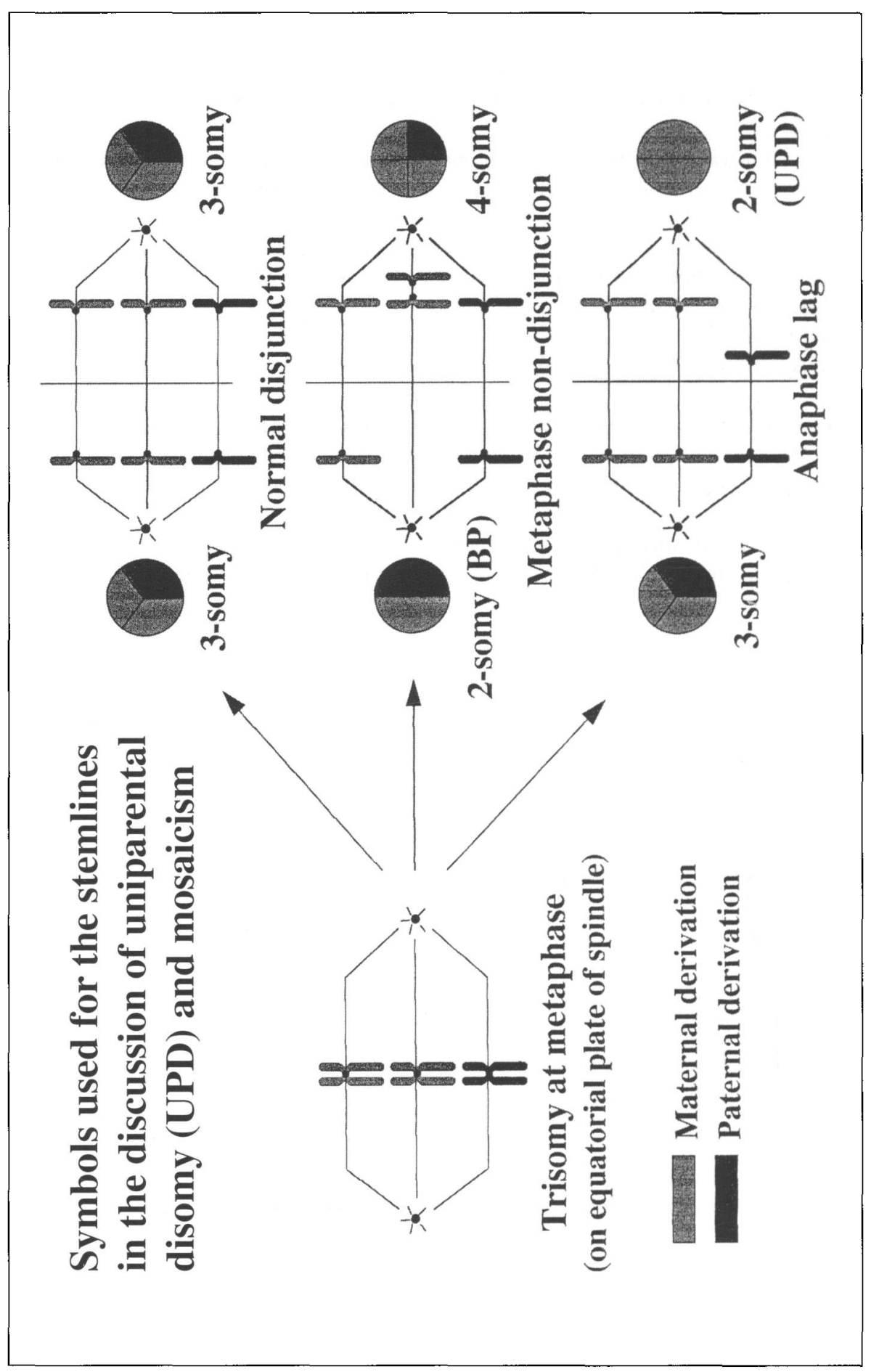

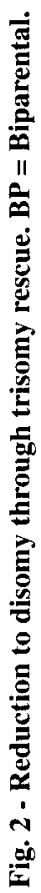




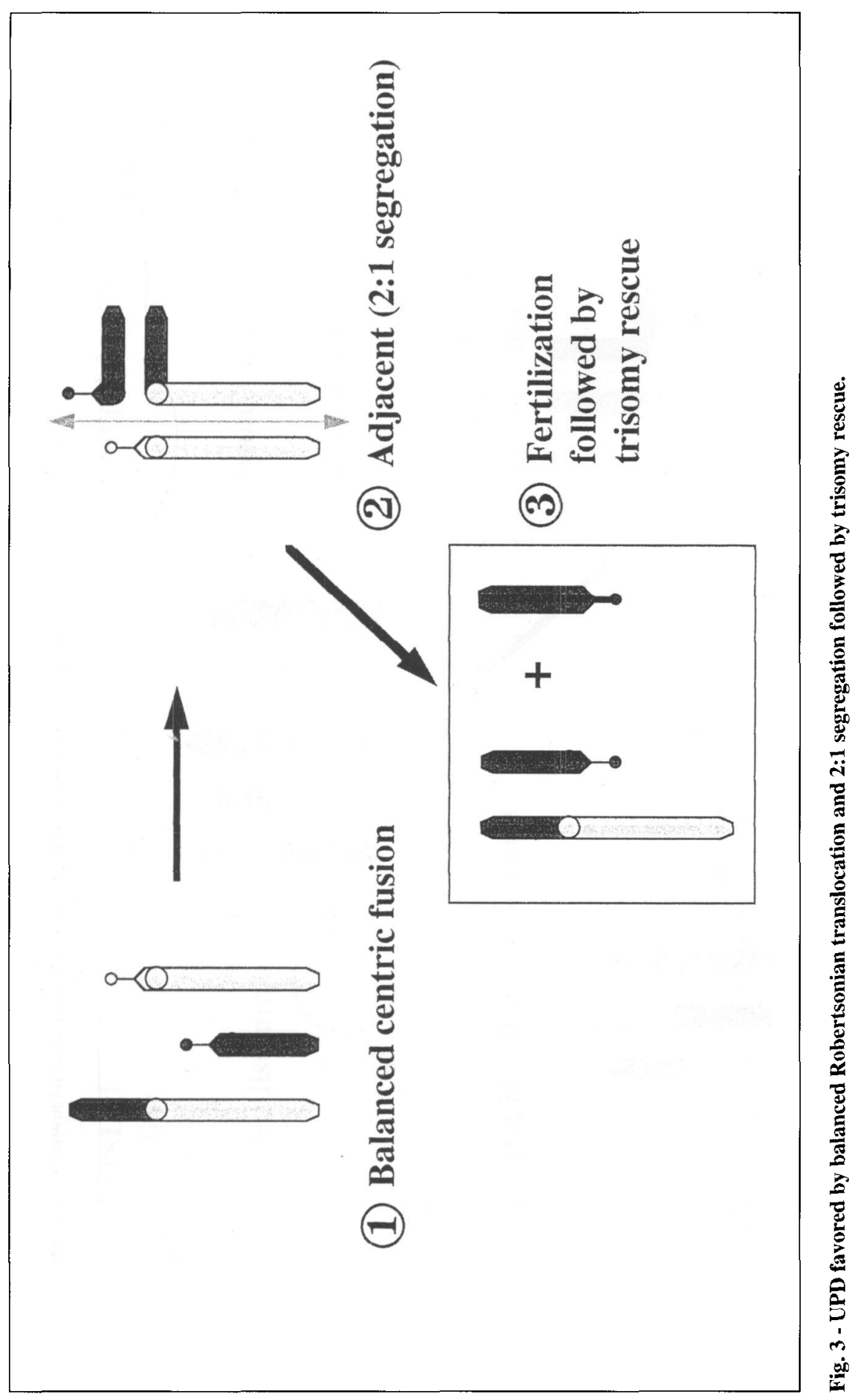




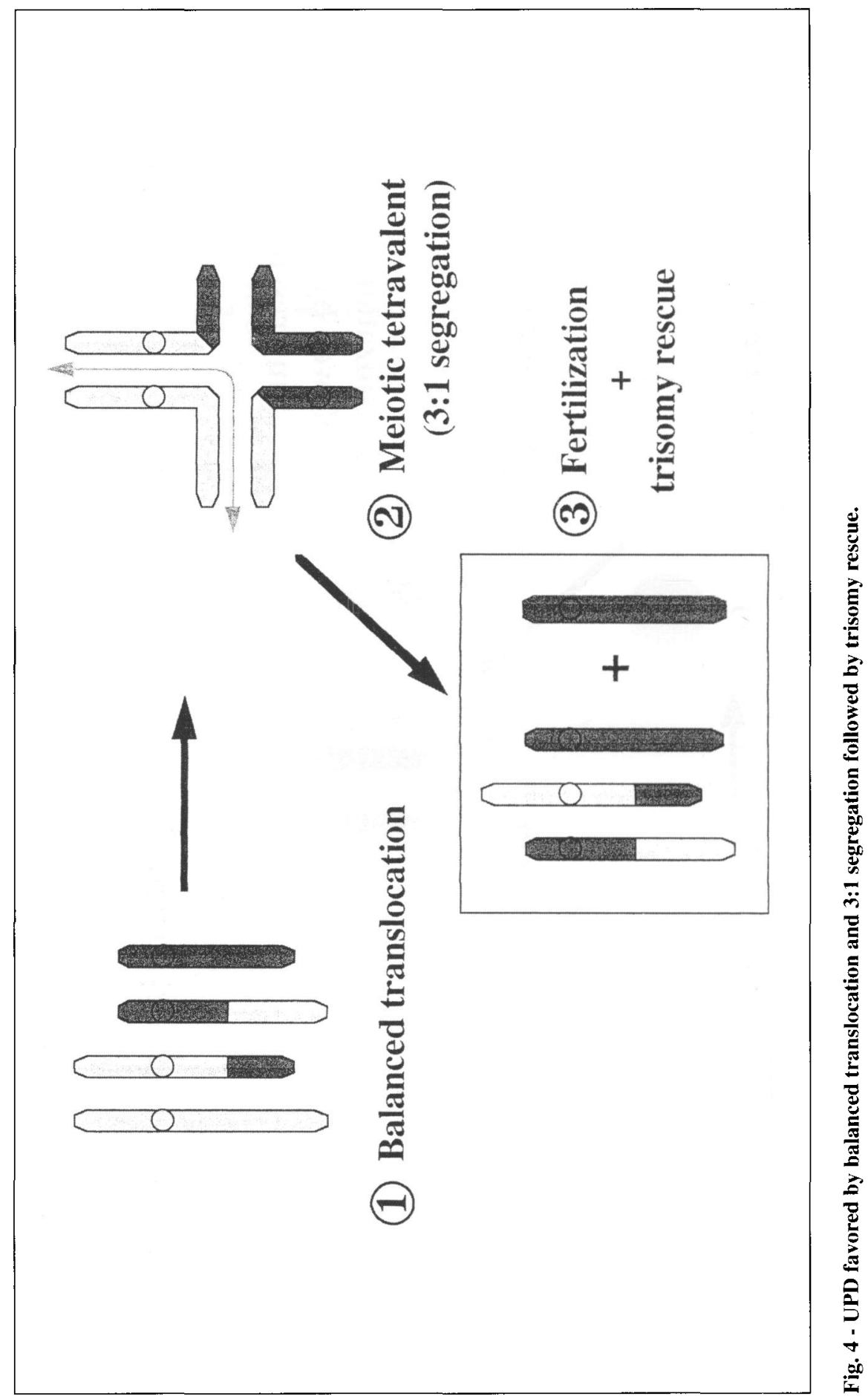

Downloaded from https:/www.cambridge.org/core. University of Basel Library, on 10 Jul 2017 at 14:54:47, subject to the Cambridge Core terms of use, available at https:/www.cambridge.org/core/terms. https://doi.org/10:1017/S0001566000001069 


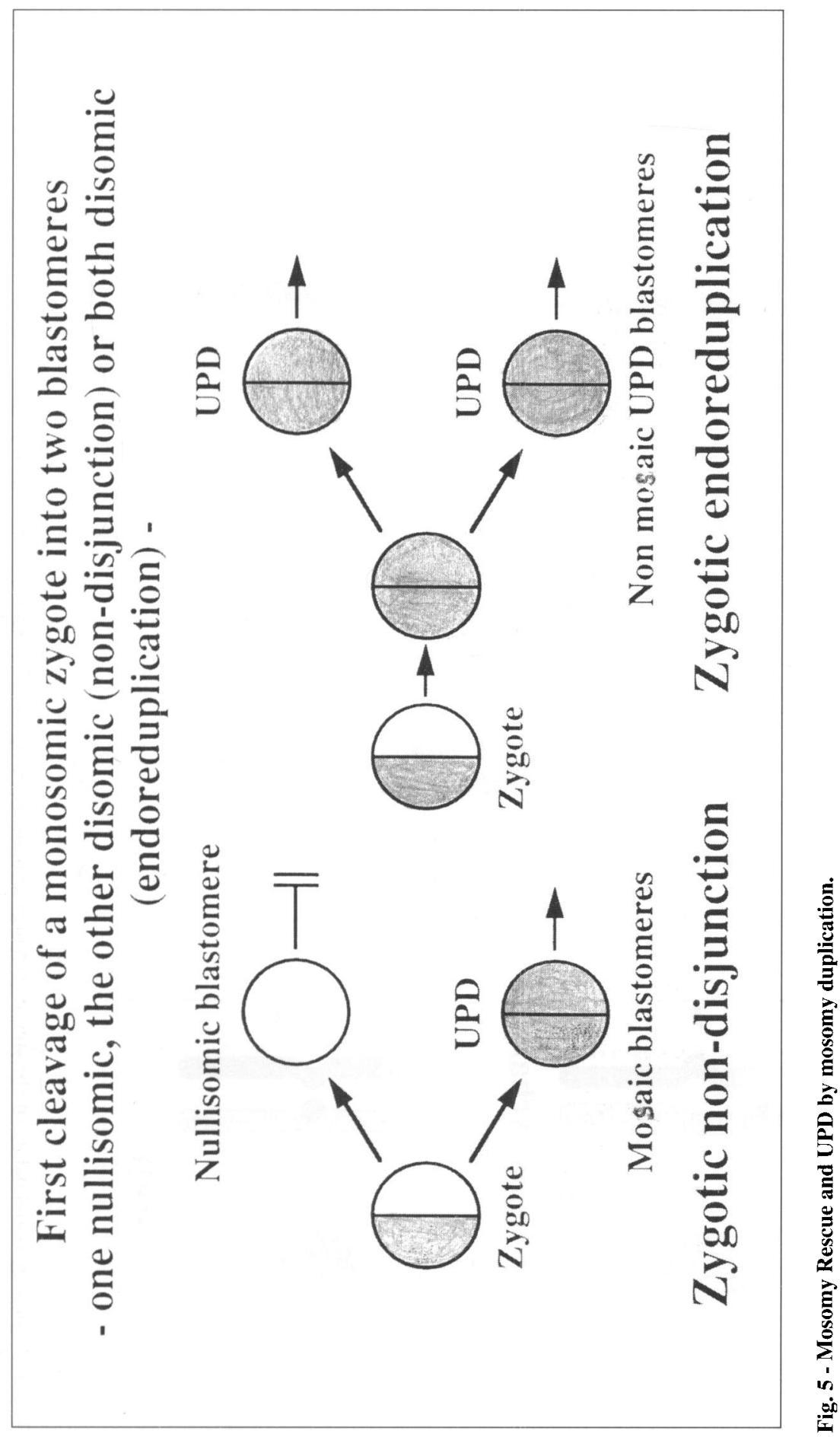




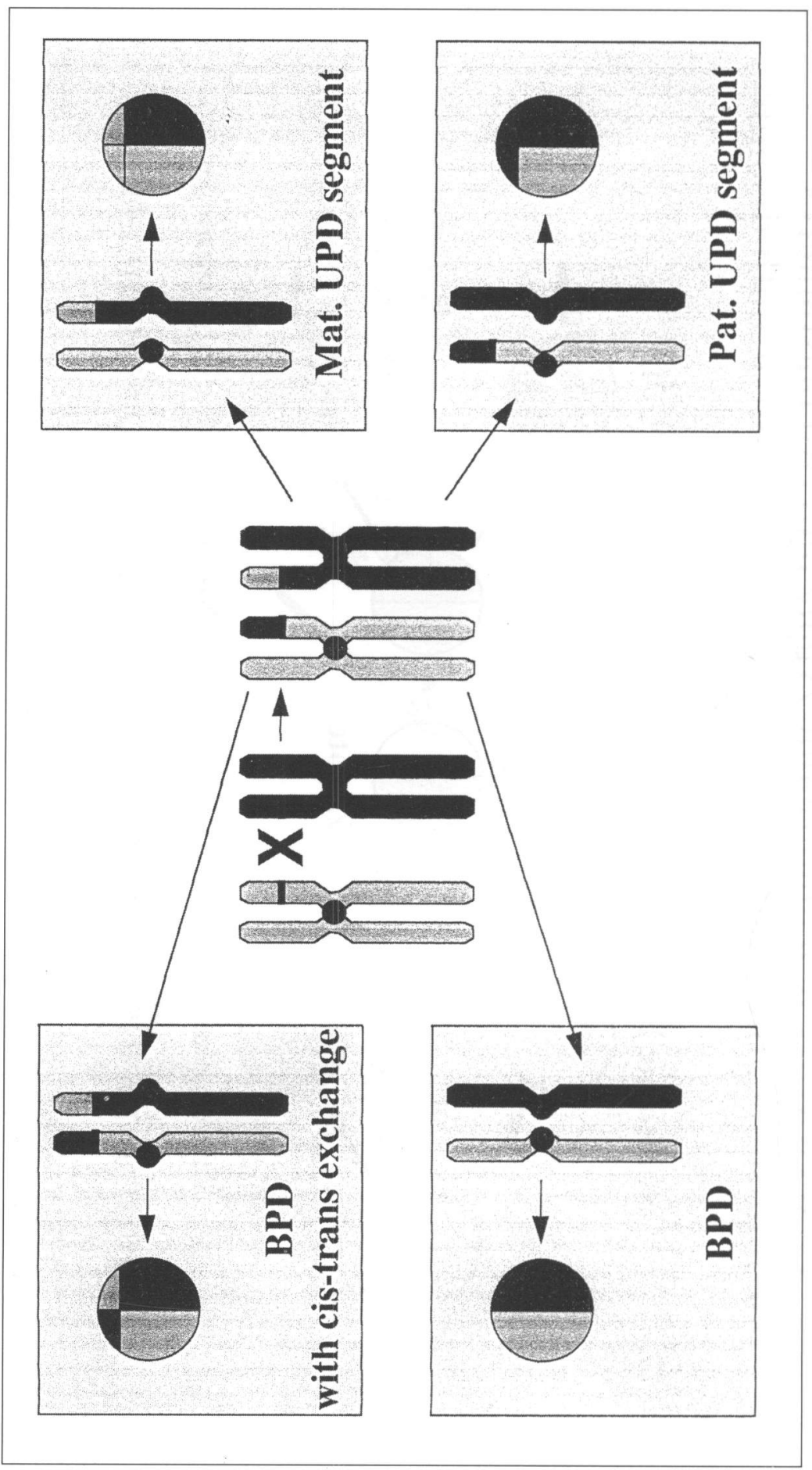

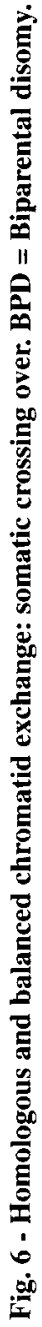




\section{Chromosomal evidence encompasses:}

1. homozygosity for a heterozygous, unique parental heteromorphism;

2. uniparental derivation of distinctive heteromorphisms of both homologues;

3. cases of homozygous pericentric inversions [30, 58];

4. balanced chromosomal interchange or Robertsonian translocation (inherited or de novo) with e.g. clinical anomalies or dysmorphism;

5. cases of euploid/aneuploid mosaicism in the proband, extraembryonic tissues or both, and

6. offspring (especially normal) born to a carrier of a Robertsonian translocation between homologues [59-62].

Molecular evidence comprises:

1. lack of obligate parental alleles $[4,10]$;

2. homozygosity acquired from a singly heterozygous parent $[4,10]$, and

3. unusual and/or excessive syntenic homozygosity [21].

\section{Evidence for the mechanisms of UPD formation}

Six mechanisms of UPD production have been documented beyond reasonable doubt in particular cases:

1. trisomy rescue (chromosomes $2,9,14,15,16$ and 20);

2. monosomy duplication including isochromosome formation (chromosomes 7,14 , 15 and 16$)$;

3. gamete complementation (chromosome 14);

4. heterochromosomal (compensatory) substitution (chromosomes 6, 15 and 21);

5. heterochromatid exchange (chromosomes 11 and 13), and

6. mosaicism.

Actual instances of reduction to homozygosity for recessive genes have been demonstrated in the conditions listed in Table 2.

Trying to take into account interfering factors such as mosaicism and isodisomy, the known cases of UPD have been scrutinized for imprinting effects to give the classification shown in Table 3 .

\section{Individual examples of imprinting related to UPD}

Maternal and paternal UPD for chromosome 15, associated with PWS and Angelman syndrome, respectively, and paternal UPD for $11 \mathrm{p} 15.5$ responsible for some cases of WBS, as obvious results of imprinting disturbances, are discussed elsewhere in this volume. Maternal UPD for chromosome 7 is associated with stunted growth (Table 4). This 
Table 2 - Clinical examples of reduction to homozygosity (isodisomy) leading to recessive diseases

\begin{tabular}{clc}
\hline Chromosome & \multicolumn{1}{c}{ Condition } & Reference \\
\hline 5 & Spinal muscular atrophy (type III) & 63 \\
6 & Deficiency of 4th component (a and b) of complement & 64 \\
& Methylmalonic acidemia & 65 \\
7 & Cystic fibrosis & 4,10 \\
& Osteogenesis imperfecta (COL1A2) & 55 \\
& Congenital chloride diarthea & 66 \\
9 & Cartilage-hair hypoplaisa & 67 \\
11 & B-thalassemia & 68 \\
14 & Retinoblastoma & 20 \\
15 & Rod monochromacy & 11 \\
16 & Bloom syndrome & 69 \\
& $\alpha$-thalassemia & 70 \\
\hline
\end{tabular}

Table 3 - Effect of known UPDs on imprinting

\begin{tabular}{lccc}
\hline Certain & Nearly certain & Possible & Unlikely \\
\hline $\operatorname{pat}(11)$ & $\operatorname{mat}(7)$ & $\operatorname{mat}(2) \mid 3] \mid$ & $\operatorname{pat}(5)|63|$ \\
$\operatorname{mat}(11)$ & $\operatorname{mat}(14)$ & $\operatorname{mat}(3)|58|$ & $\operatorname{pat}(6)[64 \mid$ \\
$\operatorname{pat}(15)$ & & $\operatorname{mat}(4)|72,73|$ & $\operatorname{mat}(7)|66|$ \\
$\operatorname{mat}(15)$ & $\operatorname{pat}(14)[7,74 \mid$ & $\operatorname{mat}(9)|67|$ \\
& $\operatorname{mat}(16)$ & $\operatorname{mat}(21) \mid 19)[61,62 \mid$ \\
& $\operatorname{pat}(20)[43]$ & $\operatorname{pat}(21) \mid 77]$ \\
& $\operatorname{pat}(\mathrm{X})[75]$ & $\operatorname{mat}(22)[78]$ \\
& & $\operatorname{mat}(\mathrm{X})[79]$ \\
& & $X Y|80|$ \\
\hline
\end{tabular}

also occurred in cases with pat $\mathrm{i}(7 \mathrm{p})$ and mat $\mathrm{i}(7 \mathrm{q})$. Consequently, the imprinted region is probably on $7 \mathrm{q}$.

The data indicating that there are genomic imprinting disturbances for maternal UPD 14 are also strong, although growth was not adversely affected in a recent case. The major signs $[11,38,46,50,51,81]$ include arrested hydrocephalus, short stature, small hands (and feet), delayed motor and/or mental development, precocious (or early) puberty and recurrent otitis media. The inconstant signs include hyperextensible joints, a short philtrum, a high narrow palate and scoliosis. 
Table 4 - Maternal UPD for chromosome 7 and genomic imprinting

\begin{tabular}{|c|c|c|c|c|c|}
\hline Sex & Age (years) & Height $(\mathrm{cm})$ & Weight $(\mathrm{kg})$ & Diagnosis & Reference \\
\hline $\mathrm{F}$ & 16 & 130 & - & $\begin{array}{l}\text { cystic fibrosis and growth } \\
\text { retardation }\end{array}$ & 4 \\
\hline M & 4 & 87 & - & $\begin{array}{l}\text { cystic fibrosis and growth } \\
\text { retardation }\end{array}$ & 10 \\
\hline M & 30 & 143.7 & 36.6 & $\begin{array}{l}\text { osteogenesis imperfecta } \\
\text { and growth retardation }\end{array}$ & 55 \\
\hline $\mathrm{F}$ & 2.25 & 76 & 7.96 & growth retardation & 56 \\
\hline
\end{tabular}

Four more cases in particular should be mentioned, whose anomalies raise the possibility of imprinting effects.

A case of maternal UPD for chromosome 2 was reported with the following phenotypic effects [31]: growth failure, hypothyroidism, bronchopulmonary problems, normal early psychomotor development and trisomy 2 mosaicism in the amniotic fluid.

Chromosome 14 paternal UPD has been associated with $[7,74]$ marked facial dysplasia, severe neurologic involvement, growth retardation and severe bone defects (of the thorax and spine in one case).

Chromosome 16 maternal UPD also has potential genomic imprinting effects. It is always derived from a trisomy of maternal origin, intrauterine growth is retarded (and positively correlated with the extent of the placental trisomy rather than with the existence of the maternal UPD per se), there is the possible implication of intrinsic (embryofetal) residual tri(16) although strict confined placental mosaicism has been claimed [39], lower gastrointestinal tract anomalies are present [82], but the natural history of this condition over time has not yet been fully documented [28].

Spinner et al. [43] have reported a case of paternal uniparental isodisomy for chromosome 20 [blood and marrow: 45, XY, t $(20 ; 20)(\mathrm{p} 13 ; \mathrm{p} 13)$ ]. The boy presented with an absent left ear, microtia of the right ear, microcephaly, congenital heart disease and Hirschsprung disease. Mosaicism for trisomy 20 in the skin was $8 \%$. This phenotype is quite distinct from $20 \mathrm{p}$ - or mosaic tri (20).

The chromosomes for which UPD is unreported as of November 1994 are mat(1), $\operatorname{pat}(1), \operatorname{pat}(2), \operatorname{pat}(3), \operatorname{pat}(4), \operatorname{mat}(5), \operatorname{mat}(6), \operatorname{mat}(8), \operatorname{pat}(8), \operatorname{pat}(9), \operatorname{mat}(10), \operatorname{pat}(10)$, mat(11), mat(12), pat(12), mat(13), mat(17), pat(17), mat(18), pat(18), mat(19), pat(19), mat(20) and pat(22).

Summarizing all the above data, a tentative imprinting map of the human genome as of February 1995, is illustrated in Figure 7.

\section{CONCLUDING REMARKS}

Imprinting, a normal epigenetic control, which depends on the parental origin of some chromosomes, may be altered at one or more loci when diploidy is, for one pair, incorrectly derived from one parental source only (UPD). Basically, whereas in normal 

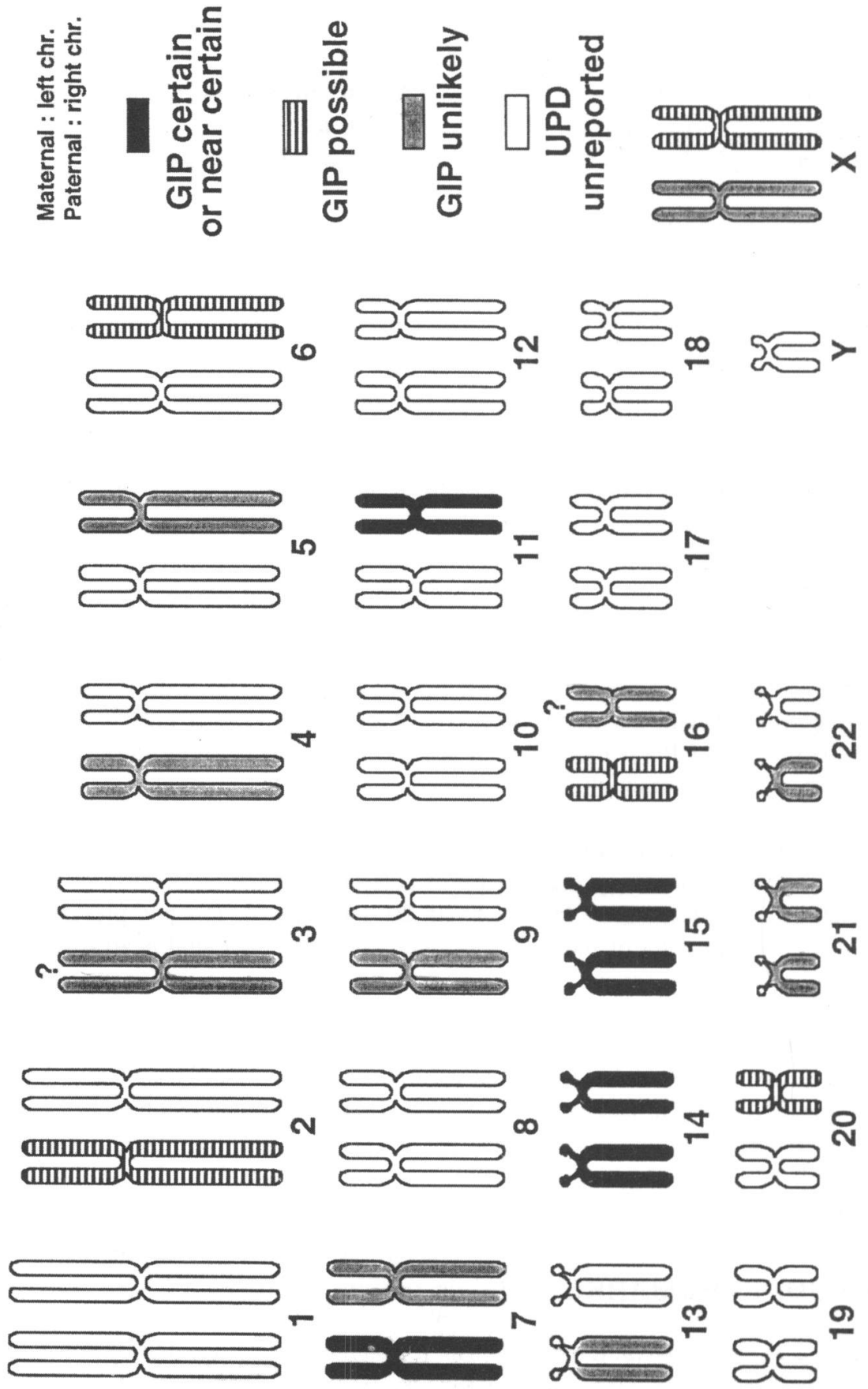


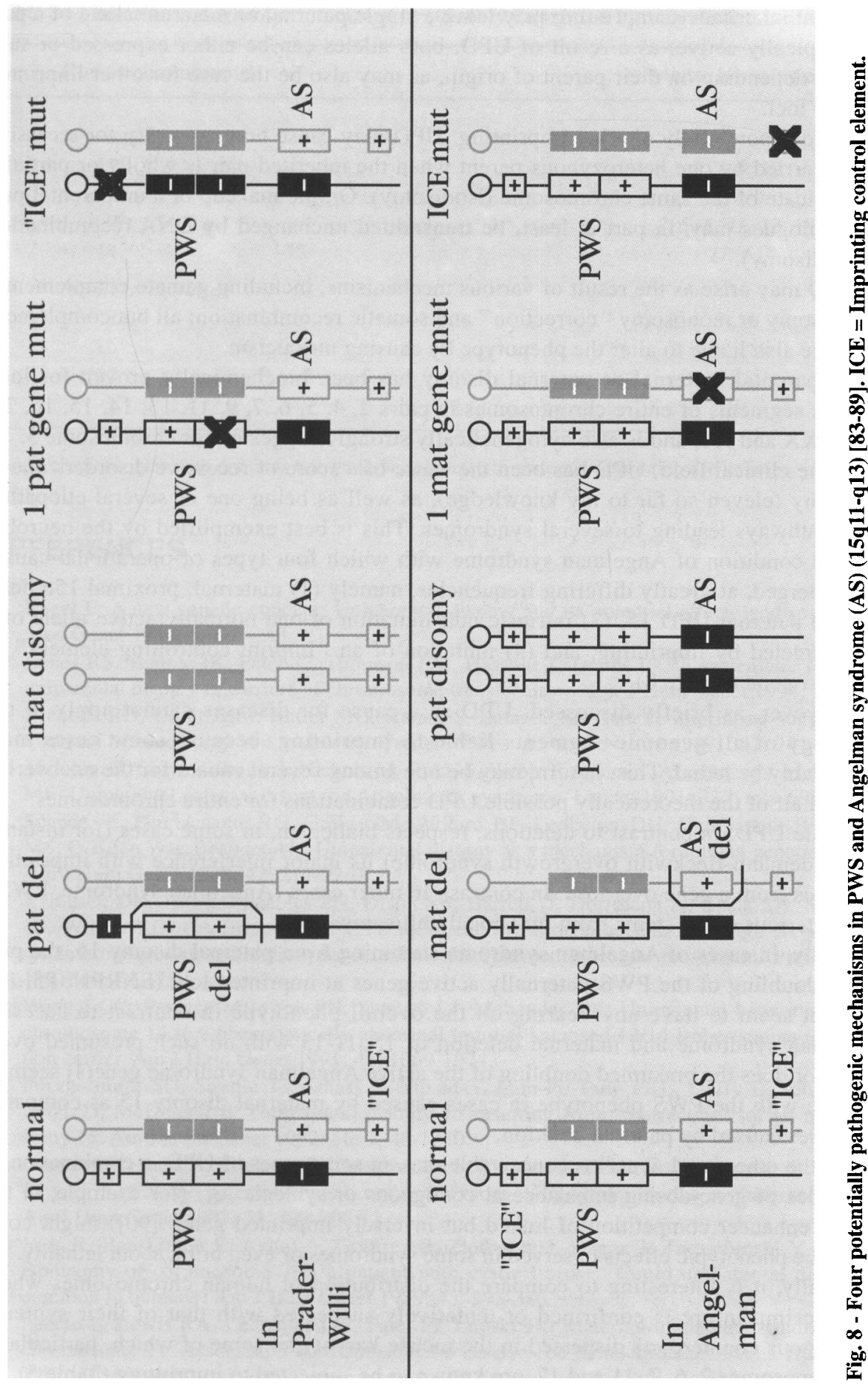


biparental inheritance, imprinting may leave a single paternal or maternal allele of a pair phenotypically active, as a result of UPD, both alleles can be either expressed or suppressed, depending on their parent of origin, as may also be the case for other imprinted syntenic loci.

Besides potentially altering imprinting, UPD may cause homozygosity for recessive alleles carried by one heterozygous parent when the inherited pair is wholly or partially the duplicate of the same chromosome (isodisomy). Or, the makeup of a uniparental pair of homologues may, in part at least, be transmitted unchanged by DNA recombination (heterodisomy).

UPD may arise as the result of various mechanisms, including gamete complementation, trisomy or monosomy "correction" and somatic recombination; all but complementation are also liable to alter the phenotype by causing mosaicism.

Uniparental maternal or paternal disomy has been biochemically proven for loci, syntenic segments or entire chromosomes in pairs $2,4,5,6,7,9,11,13,14,15,16,20$, $21,22, \mathrm{XX}$ and XY, and is also cytogenetically strongly suggested for chromosome 3.

In the clinical field, UPD has been the cause of a score of recessive disorders due to isodisomy (eleven so far to my knowledge), as well as being one of several etiopathogenic pathways leading to several syndromes. This is best exemplified by the neurobehavioral condition of Angelman syndrome with which four types of operational causes have emerged, at greatly differing frequencies, namely (1) maternal, proximal 15 q deletion, (2) paternal UPD 15, (3) intrinsic null mutation of one normally active allele of a locus targeted by imprinting, and (4) mutation of an "imprint controlling element" or imprinter gene (Figure 8).

However, as briefly discussed, UPD as a cause for diseases cannot apply to the pathology of all genomic segments liable to imprinting, because some cases must unavoidably be lethal. This, in turn, may be one among several causes for the uncovering of only half of the theoretically possible UPD combinations for entire chromosomes.

While UPD, in contrast to deletions, respects biallelism, in some cases (for instance the Wiedemann-Beckwith overgrowth syndrome) its major interference with imprinting originates from a gene overdose. In contrast, in other cases (Angelman syndrome, PWS), the deleterious effect stems from functional nullisomy.

Oddly, in cases of Angelman syndrome stemming from paternal disomy 15, the presumed doubling of the PWS paternally active genes at imprinted loci (SNRPN, P5, P1) does not seem to have any bearing on the overall phenotype in contrast to cases of Angelman syndrome and maternal deletion of 15q11-13 with no such presumed overdose. Nor does the presumed doubling of the active Angelman syndrome gene(s) seem to interfere with the PWS phenotype in cases caused by maternal disomy 15 as compared with cases caused by paternal deletion.

On the other hand, it seems conceivable that, in some cases of UPD, a combination of both types of gene-dosing imbalance at contiguous or syntenic loci (for example, in the case of enhancer competition of linked but inversely imprinted genes [90]) might compound the phenotypic effects observed in some syndromes or even bring about lethality.

Finally, it is interesting to compare the distribution of human chromosomes where genomic imprinting is confirmed or tentatively suspected with that of their syntenic homologous counterparts dispersed in the mouse karyotype, some of which, particularly on chromosomes 2, 6, 7, 11 and 17, are known to be subjected to imprinting (Table 5). 
Table 5 - Mouse homologies for imprinted or possibly imprinted human chromosomes [91]

\begin{tabular}{cc}
\hline Human chromosome & Mouse homologies \\
\hline Imprinted & \\
11 & $2,7,9,19$ \\
15 & $2,7,9$ \\
7 & $2,5,6,11,12,13$ \\
14 & 11,13 \\
Possibly imprinted & \\
2 & $1,2,6,8,11,12,17$ \\
16 & $7,8,11,16,17$ \\
20 & 2 \\
$\mathrm{X}$ & 19 \\
\hline
\end{tabular}

Mouse chromosomes with domains known to be subjected to genomic imprinting are italicize.

\section{REFERENCES}

1. Engel E: A new genetic concept: Uniparental disomy and its potential effect, isodisomy. Am J Med Genet 1980; 6: 137-143.

2. James RS, Temple IK, Patch C, Thomson EM, Hassold T, Jacobs PA: A systematic search for uniparental disomy in carriers of chromosome translocations. Eur J Hum Genet 1994; 2: 83-95.

3. Nicholls RD, Knoll JHM, Butler MG, Karam S, Lalande M: Genetic imprinting suggested by maternal heterodisomy in non-deletion Prader-Willi syndrome. Nature 1989; 342: 281-285.

4. Malcolm S, Clayton-Smith J, Nichols M, Robb S, Webb T, Armour JAL, Jeffreys AJ, Pembrey ME: Uniparental paternal disomy in Angelman's syndrome. Lancet 1991; 337: 694-697.

5. Spence JE, Perciaccante RG, Greig GM, Willard HF, Ledbetter DH, Hejtmancik JF, Pollack MS, O'Brien WE, Beaudet AL: Uniparental disomy as a mechanism for human genetic disease. Am J Hum Genet 1988; 42: 217-226.

6. Kalousek DK, Howard-Peebles PN, Olson SB, Barrett IJ, Dorfmann A, Black SH, Schulman JD, Wilson RD: Confirmation of CVS mosaicism in term placentae and high frequency of intrauterine growth retardation: association with confined placental mosaicism. Prenat Diagn 1991; 11: 743-750.

7. Wang J-CC, Passage MB, Yen PH, Shapiro LJ, Mohandas TK: Uniparental heterodisomy for chromosome 14 in a phenotypically abnormal familial balanced 13/14 Robertsonian translocation carrier. Am J Hum Genet 1991; 48: 1069-1074.

8. Purvis-Smith SG, Saville T, Manass S, Yip M-Y, Lam-Po-Tang PRL, Duffy B, Johnston H, Leigh D, McDonald B: Uniparental disomy 15 resulting from "correction" of an initial trisomy 15. Am J Hum Genet 1992; 50: 1348-1350.

9. Cassidy SB, Lai LW, Erickson RP, Magnusson L, Thomas E, Gendron R, Herrmann J: Trisomy 15 with loss of the paternal 15 as a cause of Prader-Willi syndrome due to maternal disomy. Am J Hum Genet 1992; 51: 701-708.

10. Voss R, Ben-Simon E, Avital A, Godfrey S, Zlotogora J, Dagan J, Tikoschinski Y, Hillel J: Isodisomy of chromosome 7 in a patient with cystic fibrosis: Could uniparental disomy be common in humans? Am J Hum Genet 1989; 45: 373-380.

11. Pentao L, Lewis RA, Ledbetter DH, Patel PI, Lupski JR: Maternal uniparental isodisomy for chromosome 14: Association with autosomal recessive rod monochromacy. Am J Hum Genet 1992; 50: 690-699. 
12. Freeman SB, May KM, Pettay P, Fernhoff PM, Hassold TJ: Paternal uniparental disomy in a child with a balanced 15;15 translocation and Angelman syndrome. Am J Med Genet 1993; 45: 625-630.

13. Bottani A, Robinson WP, DeLozier-Blanchet CD, Engel E, Morris M, Schmitt B, Thun Hohenstein L, Schinzel A: Angelman syndrome due to paternal uniparental disomy of chromosome 15: A milder phenotype? Am J Med Genet 1994; 51: 35-40.

14. Saitoh S, Mutirangura A, Kuwano A, Ledbetter DH, Niikawa N: Isochromosome $15 q$ of maternal origin in two Prader-Willi syndrome patients previously diagnosed erroneously as cytogenetic deletions. Am J Med Genet 1994; 50: 64-67.

15. Bettio D, Giardino D, Rizzi N, Barantani E, Volpi L, Riva P: Maternal uniparental disomy in a Prader-Willi patient with a $\mathrm{t}(15 \mathrm{q} ; 15 \mathrm{q})$ and pituitary adenoma: Fortuity or a rare association? Int. Symp. Genomic Imprinting, Florence, 1994, A 3.

16. Petersen MB, Bartsch O, Adelsberger PA, Mikkelsen M, Schwinger E, Antonarakis SE: Uniparental isodisomy due to duplication of chromosome 21 occurring in somatic cells monosomic for chromosome 21. Genomics 1992; 13: 269-274.

17. Robinson WP, Wagstaff, Bernasconi F, Baccichelti B, Artifoni L, Franzoni E, Suslak L, Shih LY, Aviv H, Schinzel AA: Uniparental disomy explains the occurrence of the Angelman or Prader-Willi syndrome in patients with an additional small inv-dup (15) chromosome. J Med Genet 1993; 30: 756-760.

18. Temple IK, James RS, Sitch FL, Howell WM, Dennis NR, Crolla JA: An imprinted gene on chromosome 6 associated with neonatal diabetes: The importance of a systematic search for uniparental disomy. Int. Symp. Genomic Imprinting, Florence, 1994, A 37.

19. Robinson WP, Bernasconi F, Basaran S, Yüksel-Apak M, Neri G, Serville F, Balicek P, Haluza R, Farah LMS, Lüleci G, Schinzel AA: A somatic origin of homologous Robertsonian translocations and isochromosomes. Am J Hum Genet 1994; 54: 290-302.

20. Cavenee WK, Dryja TP, Phillips RA, Benedict WF, Godbout R, Gallie BL, Murphree AL, Strong LC, White RL: Expression of recessive alleles by chromosomal mechanisms in retinoblastoma. Nature 1983; 305: 779-784.

21. Henry I, Bonaïti-Pellié C, Chenhensse V, Beldjord C, Schwartz C, Utermann G, Junien C: Uniparental paternal disomy in a genetic, cancer predisposing syndrome. Nature 1991; 351: 665667.

22. DeLozier-Blanchet CD, Engel E, Extermann P, Pastori B: Trisomy 7 in chorionic villi: Follow up studies of pregnancy, normal child, and placental clone anomalies. Prenat Diagn 1988; 8: 281-286.

23. Engel E, DeLozier-Blanchet CD: Uniparental disomy, isodisomy and imprinting: Probable effects in man and strategies for their detection. Am J Med Genet 1991; 40: 432-439.

24. Engel E: Uniparental disomy revisited, the first twelve years. Am J Med Genet 1993; 46: 670674.

25. Kalousek DK, Langlois S, Barrett I, Yam I, Wilson DR, Howard-Peebles PN, Johnson MP, Giorgiutti E: Uniparental disomy for chromosome 16 in humans. Am J Hum Genet 1993; 52: 8-16.

26. Bennett P, Vaugh J, Henderson D, Longhna S, Moore G: Association between confined placental trisomy, fetal uniparental disomy and early intrauterine growth retardation. Lancet 1992; 340: 1284-1285.

27. Dorfmann AD, Perszyk J, Robinson P, Black SH, Schulman JD: Rare non mosaic trisomies in chorionic villus tissue not confirmed at amniocentesis. Prenat Diagn 1992; 12: 899-902.

28. Dworniczak B, Koppers B, Bogdanova N, Exeler R, Tercanli S, Holzgreve W, Horst J, Miny P: Clinical follow up of uniparental disomy 16 (abstract 28). Am J Hum Genet 1994; (55) Suppl. A7.

29. Dworniczak B, Koppers B, Kurlemann G, Holzgreve W, Horst J, Miny P: Uniparental disomy with normal phenotype. Lancet 1992; 340: 1285.

30. Willatt LR, Clare Davison BC, Goudie D, Alexander J, Dysen HM, Jenks PE, Ferguson-Smith ME: A male with trisomy 9 mosaicism and maternal uniparental disomy for chromosome 9 in the euploid cell line. J Med Genet 1992; 29: 742-744. 
31. Harrison KB, Eisenger K, Yeboa KA, Brown S: Maternal uniparental disomy of chromosome 2 in a baby with trisomy 2 mosaicism in amniotic fluid culture (abstract 603). Am J Hum Genet 1994; 55 (Suppl.) A 106.

32. Kalousek DK, Langlois S, Harrison KJ, Wilson RD, McGillivray BC, Yong SL, Barrett IJ, Johnson M, Howard-Peebles P: Confined placental mosaicism and uniparental disomy (abstract 39). Am J Hum Genet 1994; (55) Suppl: A9.

33. Hogge WA, Schonberg SA, Golbus MS: Chorionic villus sampling: Experience of the first 1000 cases. Am J Obstet Gynecol 1986; 154: 1249-1252.

34. Mikkelsen M, Aymé S: Chromosome findings in chorionic villi: A collaborative study. 7 th Int Congr Hum Genet, Berlin, 1986.

35. Simoni G, Fraccaro M, Gimelli G: False positive and false negative findings on chorionic villus sampling. Prenat Diagn 1987; 7: 671-672.

36. Ledbetter DH, Martin AO, Verlinsky Y, et al: Cytogenetic results of chorionic villus sampling: High success rate and diagnostic accuracy in the United States collaborative study. Am J Obstet Gynecol 1990; 162: 495-501.

37. DeLozier-Blanchet CD: Anomalies cytogénétiques et fonction placentaire. Rev Fr Gynécol Obstét 1991; 86: 723-729.

38. Antonarakis S, Blouin JL, Maher J, Avramopoulos D, Thomas G, Talbot CC: Maternal uniparental disomy for human chromosome 14 , due to loss of a chromosome 14 from somatic cells with $\mathrm{t}(13 ; 14)$ trisomy 14 . Am J Hum Genet 1993; 52: 1145-1152.

39. Devi AS, Velinor M, Kamoth V, Eisenfeld L, Neu R, Ciarleglio L, Greenstein R, Benn P: Variable clinical expression of mosaic trisomy 16 in the new born infant. Am J Med Genet 1993; 47: 294-298.

40. Sirchia SM, DeAndreis C, Pariani S, Grimoldi MG, Molinari A, Buscaglia M, Simoni G: Chromosome 14 maternal uniparental disomy in the euploid cell line of a fetus with mosaic 46,XX/47,XX, + 14 karyotype. Hum Genet 1994; 94: 355-358.

41. DeLozier-Blanchet CD, Hahnemann JM, Veierslev LO: Eucromic (European collaborative research on mosaicisms in chorionic villus sampling (abstract 40). Am J Hum Genet 1994; 55 (suppl): A10.

42. Morichon-Delvallez N, Seques B, Pinson MP, Bérubé D, Dommergues M, Aubry MC, Cessot F, Lyonnet S, Munnich A, Vekemans M: Maternal uniparental disomy for chromosome 14 by secondary non-disjunction of an initial trisomy (abstract 2224). Am J Hum Genet 1994; (55 suppl): A379.

43. Spinner NB, Rand E, Bucan M, Jirik F, Gogolin-Ewens C, Riethman HC, McDonald-McGinn DM, Zackaï EH: Paternal uniparental isodisomy. for human chromosome 20 and absence of external ears (abstract 674). Am J Hum Genet 1994; (55 suppl): A118.

44. Milunsky JM, Wyandt HE, Amos JA, Kang Z, Huang XL, Elias E, Milunsky A: Trisomy 15 mosaicism in uniparental disomy (UPD) in a live born infant (abstract 636). Am J Hum Genet 1994; 55 (suppl): A112.

45. Rocklin ML, Elder FFB, Ledbetter DH, Christian S, Huang B, Rosenberg H, Sheppard C, Wilkins I: True fetal trisomy 15 mosaicism with maternal uniparental disomy (abstract 1677). Am J Hum Genet 1994; 55 (suppl): A286.

46. Temple IK, Cockwell A, Hassold T, Pettay D, Jacobs P: Maternal uniparental disomy for chromosome 14. J Med Genet 1991; 28: 511-514.

47. Hamabe JI, Fukushima Y, Harada N, Abe K, Matsuo N, Nagai T, Yoshioka A, Tonoki H, Tsukino R, Niikawa N: Molecular study of the Prader-Willi syndrome: Deletion, RFLP and phenotype analyses of 50 patients. Am J Med Genet 1991, 41: 54-63.

48. Smeets DMCF, Hamel BCJ, Nelen MR, Smeets HJM, Bollen JHM, Smits APT, Ropers HH, Van Oost BA: Prader Willi syndrome and Angelman syndrome in cousins from a family with a translocation between chromosomes 6 and 15. New Engl J Med 1992; 326: 807-811.

49. Smith A, Robson L, Neumann A, Mulcahy M, Chabros M, Deng V, Woodage ZM, Trent RJ: Fluorescence in situ hybridization and molecular studies used in the characterisation of a Robertsonian translocation (13q15q) in Prader-Willi syndrome. Clin Genet 1993; 43: 5-8. 
50. Healey S, Powell F, Battersby M, Chenevix-Trench G, McGill J: Distinct phenotype in maternal uniparental disomy of chromosome 14. Am J Med Genet 1994; 51: 147-149.

51. Tomkins DJ, Waye JS, Whelan DT, Cox DW: Maternal uniparental disomy of chromosome 14 in a boy with $t(14 q ; 14 q)$ associated with a paternal $t(13 q ; 14 q)$ (abstract 685). Am J Hum Genet 1994; 55 (suppl): A120.

52. Driscoll DJ: Genomic imprinting in humans. Mol Genet Med 1994; 4: 37-77.

53. Driscoll DJ, Waters MF, Williams CA, Zori RT, Glenn CC, Avidano KM, Nicholls RD: A DNA methylation imprint, determined by the sex of the parent, distinguishes the Angelman and Prader-Willi syndromes. Genomics 1992; 13: 917-924.

54. Schinzel AA: Uniparental disomy and gene localization. Am J Hum Genet 1991; 48: 424-425.

55. Spotila LD, Sereda L, Prockop DJ: Partial isodisomy for maternal chromosome 7 and short stature in an individual with a mutation at the COLIA2 locus. Am J Hum Genet 1992; 51: 1396-1405.

56. Eggerding FA, Schonberg SA, Chehab FF, Norton ME, Cox VA, Epstein CJ: Uniparental isodisomy for paternal $7 p$ and maternal $7 q$ in a child with growth retardation. Am J Hum Genet 1994; 55: 255-263.

57. Williams JC, Brown KW, Mott MG, Montland NJ: Maternal allele loss in Wilms tumor. Lancet 1989; i: 283-284.

58. Betz A, Turleau C, deGrouchy J: Heterozygotie et homozygotie pour une inversion péricentrique du 3 humain. Am Génét 1974; 17: 77-80.

59. Palmer CG, Schwartz S, Hodes ME: Transmission of a balanced homologous $t(22 q ; 22 q)$ translocation from mother to normal daughter. Clin Genet 1980; 17: 418-422.

60. Kirkels VGHJ, Hustinx TWJ, Scheres JMJC: Habitual abortion and translocation (22q;22q): Unexpected transmission from mother to her phenotypically normal daughter. Clin Genet 1980; 18: 456-461.

61. Stallard R, Krueger S, Schwartz S: Uniparental disomy (UD) in a normal female due to transmission of a maternal $\mathrm{t}(13 \mathrm{q} ; 13 \mathrm{q})$. Am J Hum Genet 1993; (53) (suppl): 256.

62. Slater H, Shaw JH, Dawson G, Bankur A, Forrest SM: Maternal uniparental disomy of chromosome 13 in a phenotypically normal child. J Med Genet 1994; 31: 644-646.

63. Brzustowicz LM, Alletto BA, Matscoane D, Theve R, Michand L, Chatkupt S, Sugarman E, Penchaszaden GK, Suslak L, Koenigsberger MR, Gilliam TC, Handelen BL: Paternal isodisomy for chromosome 5 in a child with spinal muscular atrophy. Am J Hum Genet 1994; 54: 482-488.

64. Welch TR, Beischel LS, Choi E, Balakrishnan K, Bishof NA: Uniparental isodisomy 6 associated with deficiency of the fourth components of complement. J Clin Invest 1990; 86: 675-678.

65. Abramowicz MJ, Adrien M, Dupont E, Dorchy H, Parma J, Duprez L, Ledley FD, Courtens W, Vamos E: Isodisomy for chromosome 6 in a newborn with methylmalonic acidemia and agenesis of pancreatic beta cells causing diabetes mellitus. J Clin Invest 1994; 94: 418-421.

66. Höglund P, Holmberg C, de la Chapelle A, Kore J: Paternal isodisomy for chromosome 7 is compatible with normal growth and development in a patient with congenital chloride diarrhea. Am J Hum Genet 1994; 55: 747-752.

67. Saliralo T, Mäkitie O, Ruuskanen O, de la Chapelle A, Kaitila J: Maternal uniparental disomy may result in an unusually severe cartilage-hair hypoplasia. Int Symp Genomic Imprinting, Florence, 1994, A33.

68. Beldjord C, Henry I, Bennani C, Vanhaeke D, Labie D: Uniparental disomy: A novel mechanism for thalassemia major. Blood 1992; 80: 287-289.

69. Woodage T, Prasad M, Dixon JW, Selby RE, Romain DR, Columbano-Green LM, Graham D, Rogan PK, Serp JR, Smith A, Trent RE: Bloom syndrome and maternal uniparental disomy for chromosome 15. Am J Hum Genet 1994; 55: 74-80.

70. Ngo KY, Lee J, Dixon B, Liu D, Jones OW: Paternal, uniparental isodisomy in a hydrops fetalis $\alpha$-thalassemia fetus. Am J Hum Genet 1993; 53 (suppl): 1207.

71. Korenstein A, Ravia Y, Avivi L: Uniparental disomy of chromosome 16 in offsprings of familial Mediterranean fever (FMF) patients treated with colchicine (abstract 616). Am J Hum Genet 1994; 55 (suppl): A109. 
72. Carpenter NJ, Say B, Barber ND: A homozygote for pericentric inversion of chromosome 4. J Med Génét 1982; 19: 469-471.

73. Lindenbaum RH, Woods CG, Norbury CG, Povey S, Rysieck G: An individual with maternal disomy of chromosome 4 and iso(4p), iso(4q). Am J Hum Genet 1991, 49 (suppl): 285.

74. Diamond TM, Mueller OT, Sutcliffe M, Papenhausen PR, Tedesco TA, Kouseff BG: Uniparental disomy for chromosome 14 Evidence for an imprinting effect. Am J Hum Genet 1993; 53: 541 .

75. Schinzel AA, Robinson WP, Binkert F, Torresani T, Werder EA: Exclusively paternal X chromosomes in a girl with short stature. Hum Genet 1993; 92: 175-178.

76. Créau-Goldberg N, Gegoine A, Delabar J, Cochet C, Cabanis MO, Stehelin D, Turleau C, deGrouchy J: Maternal origin of a de novo balanced $\mathrm{t}(2 \mathrm{qq} ; 21 \mathrm{q})$ identified by ets-2 polymorphisms. Hum Genet 1987; 76: 396-398.

77. Blouin JL, Avramopoulos D, Pangalos C, Antonarakis SE: Normal phenotype with paternal uniparental isodișomy for chromosome 21. Am J Hum Genet 1993; 53: 1074-1078.

78. Schinzel AA, Basaran S, Bernasconi F, Karaman B, Yüksel-Apak M, Robinson WP: Maternal uniparental disomy 22 has no impact on the phenotype. Am J Hum Genet 1994; 54: 21-24.

79. Avivi L, Korenstein A, Braier-Goldstein O, Goldman B, Ravia Y: Uniparental disomy of sex chromosomes in man (abstract 33). Am Soc Hum Genet 1993; El (suppl): A11.

80. Vidaud D, Vidaud M, Plassa F, Gazengel C, Noël B, Goossens M: Father-to-son transmission of hemophilia A due to uniparental disomy, (abstract 889). 40th Ann Meet Am Soc Hum Genet, 1989.

81. Bricarelli D, Borrone C, Mantero MM, Perfumo C, Guelfi M, Panucci E, Corrillo DA: Paternal uniparental disomy for chromosome 14. Int Symp Genomic Imprinting, Florence, 1994; $\mathrm{SR} / 15$.

82. Vaughan J, Ali Z, Bower S, Bennnett P, Chard T, Moore G: Human maternal uniparental disomy for chromosome 16 and fetal development. Prenat Diagn 1994; 14: 751-756.

83. Ledbetter DH, Riccardi VM, Airhart SD, Strobel RJ, Keenan BS, Crawford JD: Deletions of chromosome 15 as a cause of the Prader-Willi syndrome. New Engl J Med 1981; 304: 325-329.

84. Kaplan LC, Wharton R, Elias E, Mandell F, Donlon T, Latt SA: Clinical heterogeneity associated with deletions in the long arm of chromosome 15: Report of 3 new cases and their possible significance. Am J Med Genet 1987; 28: 45-53.

85. Wagstaff J, Knoll JHM, Glatt KA, Shugart JJ, Sommer A, Lalande M: Maternal but not paternal transmission of 15q11-13 linked non deletion Angelman syndrome leads to phenotypic expression. Nat Genet 1992; 1: 291-294.

86. Özcelik T, Leff S, Robinson W, Darlon P, Lalande M, Saupiver E, Schinzel A: Small nuclear ribonucleoprotein polysephide N (SNRPN): An expressed gene in the Prader Willi syndrome critical region. Nat Genet 1992; 2: 265-269.

87. Beaudet AL, Nakao M, Durtschi BA, Mutirangevra A, Ledbetter DH, Sutcliffe JS: Molecular analysis of the Prader-Willi Angelman critical region identifies a cluster of imprinted genes. $\mathbf{J}$ Cell Biochem 1994; 18 (suppl A): 205.

88. Reis A, Dittrich B, Greger V, Buiting K, Lalande M, Gillessen-Kaeschbach G, Anvret M, Horsthemko B: Imprinting mutations suggested by abnormal DNA methylation patterns in familial Angelman and Prader-Willi syndromes. Am J Hum Genet 1994; 54: 741-747.

89. Nicholls RD: New insights reveal complex mechanisms involved in genomic imprinting. Am J Hum Genet 1994; 54: 733-740.

90. Steenman MJC, Rainier S, Dobry CJ, Grundy P, Horan IL, Feinberg AP: Loss of imprinting of IGF2 is linked to reduced expression and abnormal methylation of H19 in Wilms tumor. Nat Genet 1994; 7: 433-439.

91. Copeland NG, Jenkins NA, Gilbert DJ: A genetic linkage map of the mouse: Current Applications and future prospects. Science 1993; 262: 57-66.

Correspondence: Eric Engel, MD, Division of Medical Genetics - 1, Rue Michel Servet, 1211 Geneva, Switzerland. 